\title{
Correction to: Irradiation-induced damage in concrete- forming aggregates: revisiting literature data through micromechanics
}

\author{
Y. Le Pape (1) · J. Sanahuja • M. H. F. Alsaid
}

Published online: 24 March 2021

(C) The Author(s) 2021

\section{Correction to: \\ Materials and Structures (2020) 53:62 https://doi.org/10.1617/s11527-020-01489-6}

The article "Irradiation-induced damage in concreteforming aggregates: revisiting literature data through micromechanics", written by Y. Le Pape,J. Sanahuja and M.H.F. Alsaid, was originally published electronically on the publisher's internet portal on 9 June 2020 without open access. The copyright of the article changed in February 2021 to (c) The Author(s) 2021 and the article is forthwith distributed under the terms of the Creative Commons Attribution 4.0 International License (https://creativecommons.org/licenses/by/4. $0 /$ ), which permits use, duplication, adaptation, distribution and reproduction in any medium or format,

The original article can be found online at https:// doi.org/10.1617/s11527-020-01489-6.

Y. Le Pape $(\bowtie)$

Oak Ridge National Laboratory, One Bethel Valley Road,

Oak Ridge, TN 37831, USA

e-mail: lepapeym@ornl.gov

J. Sanahuja

Electricité de France Lab, 77250 Moret-sur-Loing, France e-mail: julien.sanahuja@edf.fr

\section{H. F. Alsaid}

Formerly at the University of Tennessee, Knoxville,

TN 37916, USA

e-mail: mustafa.alsaid1987@gmail.com as long as you give appropriate credit to the original author(s) and the source, provide a link to the Creative Commons license and indicate if changes were made.

Open Access This article is distributed under the terms of the Creative Commons Attribution 4.0 International License (https://creativecommons.org/ licenses/by/4.0/), which permits unrestricted use, distribution, and reproduction in any medium, provided you give appropriate credit to the original author(s) and the source, provide a link to the Creative Commons license, and indicate if changes were made. Publisher's Note Springer Nature remains neutral with regard to jurisdictional claims in published maps and institutional affiliations.

Publisher's Note Springer Nature remains neutral with regard to jurisdictional claims in published maps and institutional affiliations. 